\title{
Prevalence of obesity among stroke patients in five Brazilian cities: a cross-sectional study
}

\author{
Prevalência de excesso de peso em pacientes com acidente vascular cerebral em cinco \\ cidades brasileiras
}

Vanessa Speckhahn Vicente ${ }^{2}$, Norberto Luiz Cabral',2, Vivian Nagel', Vanessa V Guesser ${ }^{1}$, Juliana Safanelli

\begin{abstract}
Objective: There is gap in knowledge about obesity prevalence in stroke patients from low- and middle-income countries. Therefore, we aimed to measure the prevalence of overweight and obesity status among patients with incident stroke in Brazil. Methods: In a crosssectional study, we measured the body mass index (BMI) of ischemic and hemorrhagic stroke patients. The sample was extracted in 2016 , from the cities of Sobral (CE), Sertãozinho (SP), Campo Grande (MS), Joinville (SC) and Canoas (RS). Results: In 1,255 patients with first-ever strokes, 64\% (95\% Cl, 62-67) were overweight and 26\% (95\% Cl, 24-29) were obese. The obesity prevalence ranged from 15\% (95\% Cl, 9-23) in Sobral to $31 \%(95 \% \mathrm{Cl}, 18-45)$ in Sertãozinho. Physical inactivity ranged from $53 \%(95 \% \mathrm{Cl}, 43-63)$ in Sobral to $80 \%(95 \% \mathrm{Cl}, 73-85)$ in Canoas. Conclusions: The number of overweight patients with incident stroke is higher than the number of patients with stroke and normal BMI. Although similar to other findings in high-income countries, we urgently need better policies for obesity prevention.
\end{abstract}

Keywords: obesity; prevalence; stroke, epidemiology; cross-sectional studies

\section{RESUMO}

Objetivo: Há uma lacuna de conhecimento sobre a prevalência de obesidade em pacientes com AVC (acidente vascular cerebral) de países de baixa e média renda. Portanto, objetivamos medir a prevalência de sobrepeso e obesidade entre pacientes com AVC no Brasil. Métodos: Em um estudo transversal, medimos o índice de massa corporal (IMC) em pacientes com AVC isquêmico e hemorrágico. A amostra foi extraída em 2016, nas cidades de Sobral (CE), Sertãozinho (SP), Campo Grande (MS), Joinville (SC) e Canoas (RS). Resultados: Entre 1255 casos de AVC, 64\% (95\% Cl, 62-67) apresentavam sobrepeso e 26\% (95\% Cl, 24-29) obesidade. A prevalência de obesidade variou de 15\% (95\% Cl, 9-23) em Sobral a 31\% (95\%Cl, 18-45) em Sertãozinho. Conclusões: A quantidade de pacientes com AVC e IMC anormal é maior do que a de pacientes com AVC e IMC normal. Embora esta prevalência seja similar às de países de alta renda, precisamos urgentemente de melhores políticas de prevenção da obesidade. Atividade física deveria ser parte da prescrição médica.

Palavras-chave: obesidade; prevalência; acidente vascular cerebral, epidemiologia; estudos transversais

Obesity has reached epidemic proportions globally, with at least 2.8 million people dying each year as a result of being overweight or obese ${ }^{1}$. Once associated with high-income countries, obesity is now also prevalent in low- and middle-income countries ${ }^{1}$. In Brazil, a study by the Ministry of Health in 2011, showed that $48 \%$ of the population was either overweight (33\%) or obese $(15 \%)^{2}$. In 2006 , these figures were $22.7 \%$ and $11.4 \%^{2,3}$.

Because obesity is believed to cause a number of established risk factors for cardiovascular diseases such as hypertension, dyslipidemia and diabetes, the growing prevalence of obesity is assumed to increase the global cardiovascular disease burden ${ }^{4}$. For instance, in adults, the risk for ischemic stroke increases almost linearly starting at a body mass index
(BMI) of $\approx 20$, and adults with a BMI of $>30 \mathrm{~kg} / \mathrm{m}^{2}$ have about a $70 \%$ increased risk for ischemic stroke compared with patients with a BMI $<25 \mathrm{~kg} / \mathrm{m}^{2.5}$. As stroke is currently the second largest cause of mortality in Brazil, we aimed to measure the prevalence of overweight and obese patients with incident stroke from five distinct Brazilian macro-regions.

\section{METHODS}

\section{Study population}

This was a cross-sectional study. We extracted data from the Joinville Stroke Registry, which has data of patients with

${ }^{1}$ Registro de AVC de Joinville, Joinville SC, Brasil;

${ }^{2}$ Universidade de Joinville (Univille), Joinville SC, Brasil.

Correspondence: Vanessa Speckhahn Vicente; Pós-Graduação e, Saúde e Meio Ambiente, Univille; Rua Paulo Malschitzk, 10; $89219-710$ Joinville SC, Brasil. E-mail: nessanutri@gmail.com

Conflict of interest: There is no conflict of interest to declare.

Received 29 September 2017; Received in final form 23 February 2018; Accepted 03 March 2018. 
first-ever stroke, from five Brazilian cities: 1. Sobral (Ceará state/northeast region); 2. Sertãozinho (São Paulo state/ southeast region); 3. Campo Grande (Mato Grosso do Sul state/midwest region); 4. Joinville (Santa Catarina state/ southern region); 5. Canoas (Rio Grande do Sul state/southern region). We used the 2016 intercensus data from the Ministry of Health ${ }^{6}$. All the cities have hospitals with computed tomography (CT) services available on a 24-hour basis. The data from cities outside Joinville were extracted from an ongoing study sponsored by the Ministry of Health and the Brazilian National Council for Scientific and Technological Development (grant 402396/2013-8).

\section{Period of data collection and ascertainment strategy}

This study sample was extracted between January and December 2016. Staff in all the cities were trained to follow the "ideal" population-based study according to the World Health Organization steps criteria ${ }^{7}$. These methods have been extensively published elsewhere ${ }^{8}$. In brief, using multiple overlapping sources, we identified all inpatients and outpatients with first-ever stroke. To evaluate hospitalized patients on a daily basis, previously-trained research nurses registered all hospitalized stroke patients confirmed by a neurologist. A neuroradiologist, unaware of the patients' symptoms, analyzed the brain CT scans and digital angiographies daily. We did not monitor patients potentially at risk (i.e., "hot pursuit"), such as those submitted to aortic, carotid, coronary, or peripheral investigation or intervention.

\section{Baseline data}

We ascertained demographic, socioeconomic data, cardiovascular risk factors and stroke severity. Cardiovascular risk factors were: hypertension (a history of treated hypertension or current use of antihypertensive medication); diabetes (a history of diabetes or current treatment for diabetes mellitus); coronary artery disease (history of angina, acute myocardial infarction, or coronary revascularization); atrial fibrillation (known previous atrial fibrillation or current treatment for atrial fibrillation); hypercholesterolemia (current treatment for hypercholesterolemia); smoking (current smoker). Stroke severity was measured with the National Institutes of Health Stroke Scales for ischemic stroke ${ }^{9}$. Minor events were defined as National Institutes of Health Stroke Scales scores $\leq 3$, moderate events as scores from 4-10, and severe events as scores $>10$. The physical activity levels were stratified in low, medium, high activity and inactive. The following criteria were used to stratify physical activity levels: 1) Inactive: no physical activities at home or work; without paid labor or recreational physical activities; 2) Low: less than 30 minutes of physical activity per day; sitting job without physical activity; 3) Moderate: sedentary work with 30 minutes to one hour physical activity per day or 30 minutes to one hour of paid labor or recreational physical activity per day; 4) Active: sedentary work with $\geq$ one hour physical activity per day; heavy manual work ${ }^{10}$. Social class was defined according to the Brazilian Criteria of Economic Classification based on the year 2013 National Household Sample Survey ${ }^{11}$.

\section{Diagnostic criteria}

We included all patients with a first-ever ischemic stroke, hemorrhagic stroke or "primary" intracerebral hemorrhage, who were residents of each of the five cities. We defined stroke as the presence of signs of sudden focal or global cerebral dysfunction lasting longer than 24 hours without any apparent nonvascular cause $^{12}$. The ischemic stroke patients were classified according to the modified Trial of Org 10172 in Acute Stroke Treatment criteria $^{13}$. The stroke investigation routine followed the guidelines of the Brazilian Society of Cerebrovascular Diseases ${ }^{14}$.

\section{Outcomes}

We used the World Health Organization criteria for overweight and obesity definitions ${ }^{15}$. The BMI (weight/height ${ }^{2}$ ) was obtained by nurse interview ${ }^{16}$. We compared the proportion of normal weight, overweight (BMI > 25) and obesity (BMI > 30) among stroke patients from five cities. The prevalence of overweight and obese patients were stratified by age, education, social class, stroke subtype, stroke severity and previous level of physical activity.

\section{Statistical analysis}

We performed descriptive statistical analyses to compare baseline characteristics using the Chi-square test, the Student's t test, or the Mann-Whitney test according to distribution. To compare proportions, we calculated binomial confidence intervals at 95\%. This study was approved by the Ethics in Research Committee.

\section{RESULTS}

We registered 1,255 first-ever stroke patients from five Brazilian cities. All cities had a medium-size country population, which means between 100,000 to 500,000 inhabitants. The demographic and socioeconomic baseline data are shown in Table 1. Except for Joinville city, the human development index was within the national cut-off point. The overall mean age was 66 years old. The proportion of patients with less than four years of education, or who were illiterate, ranged from $23 \%$ (95\%CI, 17-29) in Canoas to 59\% (95\%CI, 47-67) in Sobral. The proportion of socio-economically poor patients (class D/E) ranged from 13\% (95\%CI, 9-19) in Canoas to $48 \%$ (95\%CI, 38-58) in Sobral.

The sample distribution by stroke types, clinical severity and cardiovascular risk factors are shown in Table 2 . The proportion of hemorrhagic stroke was significantly higher in Sertãozinho city $(23 \%, 95 \% \mathrm{CI}, 13-35 ; \mathrm{p}=0.001)$. The most common type of ischemic stroke was undetermined, ranging from 41\% (95\% CI, 36-45) in Joinville to 65\% (95\% CI, 57-72) 
in Canoas. At hospital admission, almost half of the patients arrived with severe strokes in Sertãozinho and Sobral (47\%, 95\% CI, 35-60 and 47\%, 95\% CI, 38-56, respectively) as opposed to $20 \%$ (95\% CI, 16-24) in Joinville. As expected, hypertension was the most common cardiovascular risk factor. Physical inactivity ranged from 53\% (95\% CI, 43-63) in Sobral to $80 \%$ (95\% CI, 73-85) in Canoas.

From 1,255 patients with first-ever ischemic stroke and hemorrhagic stroke, $64 \%$ (95\%CI, 62-67) were overweight and $26 \%$ (95\%CI, 24-29) were obese (Tables 3 and 4). More than double the overweight and obese patients were between 55 and 74 years old. In patients with less than eight years of education, the prevalence of being overweight was 78\% (95\%CI, 75-81) and the prevalence of obesity was $69 \%$ (95\%CI, 63-74). Despite social class C having more overweight patients than patients with a normal BMI [(56\% (95\%CI, 53-60) vs 52\% (95\%CI, 48-57)], this difference was not significant (OR 1.17, 95\%CI, 0.9-1.5). This difference was also not significant when we compared obese patients [(58\% (95\%CI, 52-63) with patients with normal BMI (OR 1.2, 95\%CI, 0.9-1.7). As expected, comparing patients with normal weight versus overweight patients who were both physically inactive, those who were overweight had a $40 \%$ higher risk of stroke (OR 1.4, 95\%CI, 1.09-1.8), reaching 75\% higher odds of risk when compared with obese patients (OR 1.75, 95\%CI, 1.27-2.42).

\section{DISCUSSION}

In this cross-sectional study, with 1,255 patients from five distinct Brazilian macro-regions, we found that the number of overweight patients with first-ever stroke were greater than the number with a normal BMI and stroke. Most of the former had less than eight years of education, belonged to social class $\mathrm{C}$ and were significantly more physically inactive.

Obesity is a worldwide pandemic ${ }^{1,17,18}$. In 2010, the Global Burden of Disease Study reported that being overweight or obese was estimated to cause 3.4 million deaths, $3.9 \%$ of years of life lost, and $3.8 \%$ of disability-adjusted life-years worldwide $^{19}$. According with this study, $7 \%$ of Brazilian men and $21 \%$ of women were obese in $2013^{19}$.

As expected, these findings have an impact on the stroke burden. A recent survey compared 362,339 stroke hospitalizations in 2003-2004 to 421,815 hospitalizations in 20112012 in the EUA, and found an absolute increase from $4 \%$ to $9 \%$ in the prevalence of obesity in among adults aged 18-64 years ${ }^{20}$. In a previous population-based study conducted in Joinville, we found that $16 \%$ (95\%CI 14-19) of 601 patients with first-ever ischemic stroke were obese in the 2005-2006 period. Six years later, (2012-2013 period), the obesity prevalence of 786 ischemic stroke patients jumped significantly to

Table 1. Demographics and socioeconomic data of 1,255 patients with first-ever stroke.

\begin{tabular}{|c|c|c|c|c|c|c|}
\hline Variable & $\begin{array}{c}\text { Campo Grande } \\
\quad(n=372)\end{array}$ & $\begin{array}{l}\text { Canoas } \\
(n=205)\end{array}$ & $\begin{array}{l}\text { Joinville } \\
(n=505)\end{array}$ & $\begin{array}{l}\text { Sertãozinho } \\
\quad(n=66)\end{array}$ & $\begin{array}{l}\text { Sobral } \\
(n=107)\end{array}$ & $\begin{array}{c}\text { All } \\
(n=1,255)\end{array}$ \\
\hline \multicolumn{7}{|l|}{ Demographics } \\
\hline City population & 863,982 & 342,634 & 569,545 & 121,412 & 203,682 & $2,101,255$ \\
\hline HDI (2010) & 0.784 & 0.750 & 0.809 & 0.761 & 0.714 & $0.754^{\star}$ \\
\hline Age (SD) & $65.6(14.7)$ & $64.5(13.6)$ & $65.6(14)$ & $65.7(16.5)$ & $65.5(16)$ & $73.1(16.1)$ \\
\hline Men (\%) & $185(49.7)$ & $104(50.7)$ & $270(53.4)$ & $33(50)$ & $55(51.4)$ & $647(51.5)$ \\
\hline \multicolumn{7}{|l|}{ Education (years) } \\
\hline$\leq 4$ & $148(40.1)^{5}$ & $47(23.0)^{1}$ & $128(25.3)$ & $25(39)^{2}$ & $61(59.2)^{3}$ & $408(32.8)^{4}$ \\
\hline $4-8$ & $142(38.5)$ & $125(61.2)$ & $256(50.8)$ & $27(42.2)$ & $31(30.1)$ & $581(46.7)$ \\
\hline $9-11$ & $63(17.1)$ & $28(13.7)$ & $90(17.8)$ & $8(12.5)$ & $9(8.8)$ & $198(15.9)$ \\
\hline$\geq 11$ & $16(4.3)$ & $4(2.0)$ & $31(6.1)$ & $4(6.3)$ & $2(1.9)$ & $57(4.6)$ \\
\hline \multicolumn{7}{|c|}{ Socio-economic class } \\
\hline $\mathrm{A} 1$ & 0 & 0 & $1(0.2)$ & 0 & 0 & $1(0.1)$ \\
\hline $\mathrm{A} 2$ & $4(1.1)$ & $2(1.0)$ & $5(1.0)$ & $2(3.0)$ & 0 & $13(1.0)$ \\
\hline B1 & $7(1.9)$ & $4(2.0)$ & $13(2.6)$ & $3(4.6)$ & $4(3.7)$ & $31(2.5)$ \\
\hline B2 & $59(15.8)$ & $56(27.4)$ & $108(21.4)$ & $21(31.8)$ & $10(9.4)$ & $254(20.2)$ \\
\hline $\mathrm{C} 1$ & $88(23.6)$ & $59(28.7)$ & 163 (32.3) & $17(25.8)$ & $13(12.1)$ & $340(27.2)$ \\
\hline $\mathrm{C} 2$ & $128(34.5)$ & $57(27.8)$ & $126(24.9)$ & $9(13.6)$ & $28(26.2)$ & 348 (27.7) \\
\hline $\mathrm{D}$ & $86(23.1)$ & $26(12.6)$ & 87 (17.2) & 13 (19.7) & $48(44.9)$ & $260(20.7)$ \\
\hline E & 0 & $1(0.5)$ & $2(0.4)$ & $1(1.5)$ & $4(3.7)$ & $8(0.6)$ \\
\hline
\end{tabular}

Data are number of patients (\%) unless otherwise indicated 2016 national intercensus; HDI: human development index. *Brazil HDI; Unavailable in: one patient'; two patients ${ }^{2}$; four patients ${ }^{3} ; 10$ patients $^{4}$. 
Table 2. Stroke types, cardiovascular risk factors and severity of patients with first-ever stroke.

\begin{tabular}{|c|c|c|c|c|c|c|}
\hline Variable & $\begin{array}{l}\text { Campo Grande } \\
\quad(n=372)\end{array}$ & $\begin{array}{l}\text { Canoas } \\
(n=205)\end{array}$ & $\begin{array}{l}\text { Joinville } \\
(n=505)\end{array}$ & $\begin{array}{l}\text { Sertãozinho } \\
\quad(n=66)\end{array}$ & $\begin{array}{l}\text { Sobral } \\
(n=107)\end{array}$ & $\begin{array}{c}\text { All } \\
(n=1,255)\end{array}$ \\
\hline \multicolumn{7}{|l|}{ Stroke types } \\
\hline Hemorrhagic stroke & $53(14.2)$ & $29(14.1)$ & $44(8.7)$ & $15(22.7)$ & $19(17.8)$ & $160(12.7)$ \\
\hline Ischemic stroke & $308(85.8)$ & $176(85.8)$ & $461(91.3)$ & $51(77.3)$ & $88(82.2)$ & $1,084(86.3)$ \\
\hline Small artery occlusion & $40(13)$ & $21(12.0)$ & $87(18.8)$ & $5(9.8)$ & $24(27.3)$ & $177(16.3)$ \\
\hline Large artery occlusion & $16(5.2)$ & $23(13.0)$ & $77(16.7)$ & $5(9.8)$ & $15(17.0)$ & $136(12.6)$ \\
\hline Cardioembolic & $34(11)$ & $18(10.3)$ & $110(23.8)$ & $7(13.7)$ & $8(9.1)$ & $177(16.3)$ \\
\hline Undetermined & $218(70.8)$ & $114(64.7)$ & $187(40.5)$ & $34(66.7)$ & $41(46.6)$ & $594(54.8)$ \\
\hline \multicolumn{7}{|c|}{ National Institute of Health Stroke Scale } \\
\hline $0-3$ & $123(33.1)$ & $93(45.3)$ & $246(48.7)$ & $12(18.7)^{1}$ & $23(22.8)^{2}$ & $497(39.9)^{3}$ \\
\hline $4-10$ & $97(26.1)$ & $40(19.5)$ & $159(31.5)$ & $21(32.8)$ & $27(26.7)$ & $344(27.6)$ \\
\hline$>10$ & $152(40.8)$ & $72(35.2)$ & $100(19.8)$ & $31(48.5)$ & $51(50.5)$ & $406(32.5)$ \\
\hline \multicolumn{7}{|l|}{ Risk factors } \\
\hline Hypertension & 269 (72.3) & $137(66.8)$ & $341(67.5)$ & $39(59.0)$ & $65(60.7)$ & $851(67.8)$ \\
\hline Diabetes & $103(27.7)$ & $49(23.9)$ & $142(28.1)$ & $17(25.7)$ & $17(15.9)$ & $328(26.1)$ \\
\hline Dyslipidemia & UN & $60(29.2)$ & $146(28.9)$ & $8(12.1)$ & $21(19.6)$ & $235(18.7)$ \\
\hline Atrial fibrillation & $9(2.4)$ & $1(0.4)$ & $46(9.1)$ & $5(7.6)$ & 0 & $61(4.8)$ \\
\hline Myocardial infarction & $16(4.3)$ & $11(5.3)$ & $36(7.1)$ & $5(7.6)$ & $3(2.8)$ & $71(5.6)$ \\
\hline Smoking & $56(15)$ & $68(33.1)$ & $109(21.6)$ & $13(19.7)$ & $25(23.3)$ & $271(21.6)$ \\
\hline \multicolumn{7}{|l|}{ Physical activity } \\
\hline Inactive & $248(66.7)$ & $163(79.5)$ & $353(69.9)$ & $43(65.2)$ & $57(53.3)$ & $864(68.8)$ \\
\hline Low activity & 89 (23.9) & $35(17.1)$ & $110(21.8)$ & $9(13.6)$ & $40(37.4)$ & $283(22.6)$ \\
\hline Medium & $21(5.7)$ & $6(2.9)$ & $35(6.9)$ & $9(13.6)$ & $6(5.6)$ & $77(6.1)$ \\
\hline High activity & $14(3.7)$ & $1(0.5)$ & $7(1.4)$ & $5(7.6)$ & $4(3.7)$ & $21(2.5)$ \\
\hline
\end{tabular}

Data are number of patients (\%) unless otherwise indicated; National Institute of Health stroke scale only for ischemic strokes: Unavailable in: 2 patients'; 6

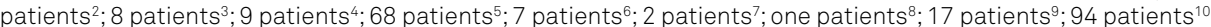

Table 3. Prevalence of overweight and obesity status in stroke patients stratified by cities.

\begin{tabular}{lcccccc}
\hline Variable & $\begin{array}{c}\text { Campo Grande } \\
(n=372)\end{array}$ & $\begin{array}{c}\text { Canoas } \\
(n=205)\end{array}$ & $\begin{array}{c}\text { Joinville } \\
(n=505)\end{array}$ & $\begin{array}{c}\text { Sertãozinho } \\
(n=66)\end{array}$ & $\begin{array}{c}\text { Sobral } \\
(n=107)\end{array}$ & $\begin{array}{c}\text { All } \\
(n=1,255)\end{array}$ \\
\hline Overweight & $250(67,2)$ & $141(68,8)$ & $323(63.9)$ & $33(63.4)$ & $60(56.1)$ & $807(65.1)$ \\
Obesity & $90(24,2)$ & $59(28,8)$ & $145(28.8)$ & $16(30.7)$ & $16(15)$ & $326(26.3)$ \\
\hline
\end{tabular}

Data are number of patients (\%) unless otherwise indicated.

$23 \%$ (95\%CI, 20-27) $)^{8}$. This proportion is similar to our finding of $26 \%$ (95\%CI, 24-29) in this study from five Brazilian cities. Table 5 shows the prevalence of patients with stroke being overweight or obese, from different countries and peri$\operatorname{ods}^{21,22,23,24,25,26,27}$. Our findings were similar to a Finland cohort ${ }^{22}$ but higher than those from Germany and China ${ }^{23,24,25,26,27}$.

The causality between obesity and stroke is debatable ${ }^{18,19,20}$. A meta-analysis of 21 cohort studies reported that risk of ischemic stroke was $22 \%$ in patients who were overweight and $64 \%$ among those who were obese. For "primary" intracerebral hemorrhage, the risk was not significant ${ }^{28}$. Nevertheless, other studies have shown that the association with obesity was substantially attenuated after the control of hypertension and diabetes variables for obesity ${ }^{24}$.
This is study has some limitations. As a cross-sectional analysis, we cannot assess the causality of the associations. The BMI data were obtained by nurse interview and have the possibility of information bias. Unfortunately, abdominal circumference measurement and diet habits were not extracted. The strengths include the large sample extracted from a prospective, population-based study, which showed, to the best of our knowledge, a prevalence of higher BMI among stroke patients from a large middle-income country.

In conclusion, we found that the number of patients who were overweight and had a stroke was greater than the number of patients with stroke and normal BMI. Furthermore, by extracting data from cities from northeast, southeast and southern Brazil, our findings endorse that we need strong educational campaigns focusing on prevention of this condition. 
Table 4. Normal BMI, overweight and obesity prevalence stratified by age, education, social class, stroke type and severity and physical activity of patients with stroke.

\begin{tabular}{|c|c|c|c|}
\hline Variable & $\mathrm{BMI}<25(\mathrm{n}=432)$ & $\mathrm{BMI} \geq 25(n=807)$ & $\mathrm{BMI} \geq 30(n=326)$ \\
\hline \multicolumn{4}{|l|}{ Age (years) ${ }^{1}$} \\
\hline$<15$ & $1(0,2)$ & 0 & 0 \\
\hline $15-34$ & $19(4,4)$ & $18(2,2)$ & $7(2,1)$ \\
\hline $35-54$ & $62(14,4)$ & $164(20,3)$ & $80(24,6)$ \\
\hline $55-74$ & $199(46,1)$ & $422(52,4)$ & $168(51,5)$ \\
\hline $75-94$ & $144(33,3)$ & $202(25,0)$ & $71(21,8)$ \\
\hline$>94$ & $7(1,6)$ & $1(0,1)$ & 0 \\
\hline All & $432(34,9)$ & $807(65,1)$ & $326(26,3)$ \\
\hline \multicolumn{4}{|l|}{ Education (years) ${ }^{2}$} \\
\hline$<4$ & $149(34,9)^{6}$ & $253(31,5)^{5}$ & $88(27,2)^{3}$ \\
\hline $4-8$ & $197(46,0)$ & $376(46,9)$ & $163(50,5)$ \\
\hline $9-11$ & $61(14,2)$ & $137(17,1)$ & $59(18,3)$ \\
\hline$>11$ & $21(4,9)$ & $36(4,5)$ & $13(4,0)$ \\
\hline \multicolumn{4}{|l|}{ Social class ${ }^{3}$} \\
\hline A1 & 0 & $1(0,1)$ & 0 \\
\hline $\mathrm{A} 2$ & $5(1,1)$ & $8(1,0)$ & $3(0,9)$ \\
\hline B1 & $13(3,0)$ & $17(2,1)$ & $5(1,5)$ \\
\hline B2 & $73(16,9)$ & $178(22,1)$ & $82(25,2)$ \\
\hline $\mathrm{C} 1$ & $98(22,8)$ & $238(29,5)$ & $98(30,1)$ \\
\hline $\mathrm{C} 2$ & $128(29,7)$ & $217(26,9)$ & $90(27,6)$ \\
\hline $\mathrm{D}$ & $110(25,4)$ & $146(18,1)$ & $48(14,7)$ \\
\hline$E$ & $5(1,1)$ & $2(0,2)$ & 0 \\
\hline \multicolumn{4}{|l|}{ Stroke type ${ }^{4}$} \\
\hline Ischemic & $366(84,7)$ & $706(87,5)$ & $285(87,4)$ \\
\hline Small artery occlusion & $64(17,5)$ & $113(16,0)$ & $46(16,1)$ \\
\hline Cardioembolic & $62(16,9)$ & $114(16,1)$ & $53(18,6)$ \\
\hline Large artery occlusion & $61(16,7)$ & $74(10,5)$ & $29(10,2)$ \\
\hline Undetermined & $179(48,9)$ & $405(57,4)$ & $157(55,1)$ \\
\hline Hemorrhagic & $66(15,3)$ & $101(12,5)$ & $41(12,6)$ \\
\hline \multicolumn{4}{|c|}{ National Institute of Health stroke scale ${ }^{5}$} \\
\hline$<4$ & $162(37,9)^{5}$ & $334(41,5)^{3}$ & $128(39,6)^{3}$ \\
\hline $4-10$ & $109(25,6)$ & $229(28,5)$ & $109(33,7)$ \\
\hline$>10$ & $156(36,5)$ & $241(30)$ & $86(26,7)$ \\
\hline \multicolumn{4}{|l|}{ Physical activity ${ }^{6}$} \\
\hline Inactive & $275(63,6)$ & $574(71,2)$ & $246(75,5)$ \\
\hline Low & $119(27,6)$ & $164(20,3)$ & $58(17,8)$ \\
\hline Medium & $24(5,6)$ & $52(6,4)$ & $17(5,2)$ \\
\hline High & $14(3,2)$ & $17(2,1)$ & $5(1,5)$ \\
\hline
\end{tabular}

BMI: body mass index; Data are number of patients (\%) unless otherwise indicated BMI: body mass index. Unavailable in: 16 patients $; 22$ patients $^{2} ; 3$ patients ${ }^{3}$ 2 patients $; 5$ patients $;$; patients $;$; Social class according to the Research Companies Brazilian Association.

Table 5. Prevalence of overweight and obesity status among cohorts of stroke patients from 1951 to 2016.

\begin{tabular}{|c|c|c|c|c|}
\hline Study & Year & Sample & Overweight prevalence & Obesity prevalence \\
\hline Aparicio et al, USA ${ }^{21}$ & $1951-2011$ & 782 & $68.5(65.1-71.8)$ & $24.3(21.3-27.5)$ \\
\hline Hu et al, Finland 22 & $1972-2004$ & 3,228 & $68.9(67.3-70.5)$ & $24.6(23.1-26.1)$ \\
\hline Wang et al, China ${ }^{24}$ & $1987-1998$ & 1,108 & $32.4(29.6-35.2)$ & $4.7(3.6-6.2)$ \\
\hline Mitchell et al, EUA ${ }^{25}$ & $1992-2008$ & 1,201 & 70.7 (68.1-75.9) & $39.5(36.7-42.3)$ \\
\hline Park et al, USA/CA/SCO 26 & 1997-2001 & 852 & $73(69.9-75.9)$ & $31.6(28.5-34.8)$ \\
\hline TEMPiS, Germany ${ }^{27}$ & $2003-2005$ & 1,521 & $58(55.5-60.5)$ & $19.4(17.4-21.5)$ \\
\hline Joinville, Brazil ${ }^{8}$ & $2005-2006$ & 610 & ---- & $16.2(13.4-15.4)$ \\
\hline Kailuan, China ${ }^{28}$ & $2006-2007$ & 1,547 & $55.7(53.2-58.2)$ & $9.9(8.5-11.5)$ \\
\hline Joinville, Brazil ${ }^{8}$ & $2012-2013$ & 786 & ---- & $23.4(20.5-26.5)$ \\
\hline 5 Brazilian cities & 2016 & 1,255 & $64.3(61.6-66.9)$ & $25.9(23.9-28.5)$ \\
\hline
\end{tabular}


1. World Health Organization - WHO. 10 facts on obesity. Geneva: World Health Organization; 2017 [cited 2017 Apr 20]. Available from: http://www.who.int/features/factfiles/obesity/en/

2. Ministério da Saúde (BR). Plano de ações estratégicas para o enfrentamento das Doenças Crônicas Não Transmissíveis (DCNT) no Brasil 2011-2022. Brasília, DF: Ministério da Saúde; 2011 [cited 2016 May 5]. Available from: http://bvsms.saude.gov.br/bvs/publicacoes/ plano_acoes_enfrent_dent_2011.pdf

3. Arbex AK, Rocha DR, Aizenberg M, Ciruzzi MS. Obesity epidemic in Brazil and Argentina: a public health concern.J Health Popul Nutr. 2014 Jun;32(2):327-34. Available from: https://www.ncbi.nlm.nih. gov/pmc/articles/PMC4216968/

4. Kernan WN, Inzucchi SE, Sawan C, Macko RF, Furie KL. Obesity: a stubbornly obvious target for stroke prevention. Stroke. 2013 Jan;44(1):278-86. https://doi.org/10.1161/STROKEAHA.111.639922

5. Kernan WN, Dearborn JL. Obesity increases stroke risk in young adults: opportunity for prevention. Stroke. 2015 Jun;46(6):1435-6. https://doi.org/10.1161/STROKEAHA.115.009347

6. Ministério da Saúde (BR). DATASUS. Estatísticas vitais. 2015 [cited 2015 Aug 20]. Available from: http://tabnet.datasus.gov.br/cgi/ deftohtm.exe?ibge/cnv/popsc.def

7. Truelsen T, Heuschmann PU, Bonita R, Arjundas G, Dalal P, Damasceno A et al. Standard method for developing stroke registers in low-income and middle-income countries: experiences from a feasibility study of a stepwise approach to stroke surveillance (STEPS Stroke). Lancet Neurol. 2007 Feb;6(2):134-9. https://doi.org/10.1016/S1474-4422(06)70686-X

8. Cabral NL, Cougo-Pinto PT, Magalhaes PS, Longo AL, Moro CH, Amaral CH et al. Trends of stroke incidence from 1995 to 2013 in Joinville, Brazil. Neuroepidemiology. 2016;46(4):273-81. Available from: https://doi.org/10.1159/000445060

9. Haskell WL, Lee IM, Pate RR, Powell KE, Blair SN, Franklin BA et al.; American Heart Association. Physical activity and public health: updated recommendation for adults from the American College of Sports Medicine and the American Heart Association. Circulation. 2007 Aug;116(9):1081-93. https://doi.org/10.1161/CIRCULATIONAHA.107.185649

10. The National Institute of Neurological Disorders and Stroke rt-PA Stroke Study Group. Tissue plasminogen activator for acute ischemic stroke. N Engl J Med. 1995;333(24):1581-8. https://doi.org/10.1056/NEJM199512143332401

11. Associação de Empresas Brasileiras de Pesquisa. Critério de classificação econômica Brasil. São Paulo: ABEP; 2008.

12. World Health Organization - WHO. The World Health Report 2000: health systems: improving performance. Geneva, World Health Organization; 2000.

13. Adams HPJr, Bendixen BH, Kappelle LJ, Biller J, Love BB, Gordon DL et al. Classification of subtype of acute ischemic stroke: definitions for use in a multicenter clinical trial. TOAST. Trial of Org 10172 in Acute Stroke Treatment. Stroke. 1993 Jan;24(1):35-41. https://doi.org/10.1161/01.STR.24.1.35

14. Oliveira-Filho J, Martins SC, Pontes-Neto OM, Longo A, Evaristo EF, Carvalho JJ et al. Guidelines for acute ischemic stroke treatment: part I. Arq Neuropsiquiatr. 2012 Aug;70(8):621-9. https://doi.org/10.1590/S0004-282X2012000800012
15. World Health Organization - WHO. WHO obesity and overweight. 2016 [cited 2016 Sep 15]. Available from: http://www.who.int/ mediacentre/factsheets/fs311/en/

16. Baggio JA, Santos-Pontelli TE, Cougo-Pinto PT, Camilo M, Silva NF, Antunes P et al. Validation of a structured interview for telephone assessment of the modified Rankin Scale in Brazilian stroke patients. Cerebrovasc Dis. 2014;38(4):297-301. https://doi.org/10.1159/000367646

17. Chong JY, Sacco RL. Epidemiology of stroke in young adults: race/ ethnic differences. J Thromb Thrombolysis. 2005 Oct;20(2):77-83. https://doi.org/10.1007/s11239-005-3201-9

18. Dehlendorff C, Andersen KK, Olsen TS. Body mass index and death by stroke: no obesity paradox. JAMA Neurol. 2014 Aug;71(8):978-84. https://doi.org/10.1001/jamaneurol.2014.1017

19. Ng M, Fleming T, Robinson M, Thomson B, Graetz N, Margono C et al. Global, regional, and national prevalence of overweight and obesity in children and adults during 1980-2013: a systematic analysis for the Global Burden of Disease Study 2013. Lancet. 2014 Aug;384(9945):766-81. https://doi.org/10.1016/S0140-6736(14)60460-8

20. George MG, Tong X, Bowman BA. Prevalence of Cardiovascular Risk Factors and Strokes in Younger Adults. JAMA Neurol. 2017 Jun;74(6):695-703. https://doi.org/10.1001/jamaneurol.2017.0020

21. Aparicio HJ, Himali JJ, Beiser AS, Davis-Plourde KL, Vasan RS, Kase CS et al. Overweight, Obesity, and Survival After Stroke in the Framingham Heart Study. J Am Heart Assoc. 2017 Jun;6(6):e004721. https://doi.org/10.1161/JAHA.116.004721

22. Hu G, Tuomilehto J, Silventoinen K, Sarti C, Männistö S, Jousilahti P. Body mass index, waist circumference, and waist-hip ratio on the risk of total and type-specific stroke. Arch Intern Med. 2007 Jul;167(13):1420-7. https://doi.org/10.1001/archinte.167.13.1420

23. Wang C, Liu Y, Yang Q, Dai X, Wu S, Wang W et al. Body mass index and risk of total and type-specific stroke in Chinese adults: results from a longitudinal study in China. Int J Stroke. 2013 Jun;8(4):245-50. https://doi.org/10.1111/j.1747-4949.2012.00830.x

24. Mitchell AB, Cole JW, McArdle PF, Cheng YC, Ryan KA, Sparks MJ et al. Obesity increases risk of ischemic stroke in young adults. Stroke. 2015 Jun;46(6):1690-2. https://doi.org/10.1161/STROKEAHA.115.008940

25. Park JH, Lee J, Ovbiagele B. Association of Optimal Combination Drug Treatment with Obesity Status among Recent Ischemic Stroke Patients: Results of the Vitamin Intervention for Stroke Prevention (VISP) Trial. J Stroke. 2017 May;19(2):213-21. https://doi.org/10.5853/jos.2016.01347

26. Doehner W, Schenkel J, Anker SD, Springer J, Audebert HJ. Overweight and obesity are associated with improved survival, functional outcome, and stroke recurrence after acute stroke or transient ischaemic attack: observations from the TEMPiS trial. Eur Heart J. 2013 Jan;34(4):268-77. https://doi.org/10.1093/eurheartj/ehs340

27. Wang A, Wu J, Zhou Y, Guo X, Luo Y, Wu S et al. Measures of adiposity and risk of stroke in China: A result from the Kailuan study. PLoS One. 2013 Apr;8(4):e6165. https://doi.org/10.1371/journal.pone.0061665

28. Strazzullo P, D’Elia L, Cairella G, Garbagnati F, Cappuccio FP, Scalfi L. Excess body weight and incidence of stroke: meta-analysis of prospective studies with 2 million participants. Stroke. 2010 May;41(5):e418-26. https://doi.org/10.1161/STROKEAHA.109.576967 